\title{
Effects of Hatha Yoga on caregivers of children and adolescents with cancer: a randomized controlled trial
}

\author{
Efeitos do Hatha-Yoga em cuidadores de crianças e adolescentes com câncer: um estudo \\ randomizado e controlado \\ Efectos del Hatha-Yoga en cuidadores de niños y adolescentes con cáncer: un estudio \\ aleatorizado y controlado
}

\begin{abstract}
Marina Lima Daleprane Bernardi ${ }^{1}($ C)
Maria Helena Costa Amorim ${ }^{1}$ (I)

Luciane Bresciane Salaroli ${ }^{1}$ (D)

Eliana Zandonade ${ }^{1}$ (iD)
\end{abstract}

1. Universidade Federal do Espírito Santo.

Vitória, ES, Brasil.
Corresponding author:

Marina Lima Daleprane Bernardi.

E-mail: mamadaleprane@hotmail.com

Submitted on 05/10/2019.

Accepted on 09/10/2019.

DOI: 10.1590/2177-9465-EAN-2019-0133

\begin{abstract}
Objective: To assess the effects of a Hatha Yoga intervention on anxiety, subjective well-being, and attention levels of caregivers of children and adolescents with cancer, admitted to a public hospital in the city of Vitória, state of Espirito Santo, Brazil. Methods: A randomized controlled trial was performed. Thirty-six volunteers were allocated to clinical (participated in 4 to 6 Hatha Yoga practices) or control groups and answered the questionnaires State-Trait Anxiety Inventory, Subjective Well-Being Scale, and Mindfulness Attention Awareness Scale before and after the intervention period. Mann-Whitney and Wilcoxon nonparametric analyses were performed to compare the groups to each other and at different moments. Results: The individuals' moderate anxiety state decreased in the clinical $(p=0.001)$ and control $(p=0.014)$ groups so that while the control group continued to present moderate anxiety, the clinical group presented low anxiety after the intervention. Positive affects increased, and adverse effects decreased in the clinical group $(p<0.05)$. There were no relevant changes in satisfaction with life and attention levels in the two groups $(p>0.05)$. Conclusion and implications for practice: Hatha Yoga is a useful tool for healthcare professionals and caregivers in short-term hospital care to reduce anxiety and improve subjective well-being.
\end{abstract}

Keywords: Cancer; Caregivers; Yoga; Anxiety; Mindfulness.

\section{Resumo}

Objetivo: Avaliar os efeitos da intervenção Hatha-Yoga nos níveis de ansiedade, bem-estar subjetivo e atenção de cuidadores de crianças e adolescentes com câncer, internados em um hospital público na cidade de Vitória, Espírito Santo, Brasil. Método: Realizou-se um ensaio clínico randomizado e controlado. Trinta e seis voluntários foram alocados em grupos clínico (participaram de 4 a 6 práticas de Hatha-Yoga) ou controle; e responderam aos questionários: Inventário de Ansiedade Traço-Estado, Escala de Bem-Estar Subjetivo, Escala de Atenção Plena e Consciência; antes e após o período correspondente à intervenção Realizaram-se análises não paramétricas de Mann-Whitney e Wilcoxon para comparar os grupos entre si e em momentos diferentes. Resultados: $O$ estado de média ansiedade dos indivíduos diminuiu nos grupos - clínico $(p=0,001)$ e controle $(p=0,014)$-, de modo que enquanto o controle permaneceu com média ansiedade, o clínico passou a apresentar baixa ansiedade. Os afetos positivos aumentaram e os negativos diminuíram no grupo clínico $(p<0,05)$. Não houve alterações relevantes nos niveis de satisfação com a vida e atenção nos 2 grupos $(p>0,05)$. Conclusão e implicações para prática: $O$ Hatha-Yoga é uma ferramenta útil aos profissionais de saúde e aos cuidadores em curto período de assistência hospitalar, na redução da ansiedade e melhoria do bem-estar subjetivo.

Palavras-chave: Câncer; Cuidadores; loga; Ansiedade; Atenção Plena.

\section{Resumen}

Objetivo: evaluar los efectos de la intervención de Hatha-Yoga sobre los niveles de ansiedad, así como el bienestar subjetivo y la atención de los cuidadores de niños y adolescentes con cáncer, ingresados en un hospital público en la ciudad de Vitória Espírito Santo, Brasil. Métodos: se realizó un ensayo clínico randomizado y controlado. Treinta y seis voluntarios fueron asignados a grupo clínico (participaron en 4 a 6 prácticas de Hatha-Yoga) o de control; y respondieron a los cuestionarios: Inventario de Ansiedad Trazo-Estado, Escala de Bienestar Subjetivo, Escala de Atención Plena y Conciencia; antes y después del período de la intervención. Se realizaron análisis no paramétricos de Mann-Whitney y Wilcoxon para comparar los grupos entre $\mathrm{s}$ y en distintos momentos. Resultados: el estado de ansiedad promedio de los individuos disminuyó en los grupos clínicos $(p=0,001)$ y de control $(p=0,014)$, de modo que mientras el control permaneció con ansiedad mediana, el clínico comenzó a presentar ansiedad baja. Los efectos positivos aumentaron y los efectos negativos disminuyeron en el grupo clínico $(p<0,05)$ No hubo cambios relevantes en los niveles de satisfacción con la vida y de atención en ambos grupos ( $p>0,05)$. Conclusión e implicaciones para la práctica: Hatha-Yoga es una herramienta útil para profesionales de la salud y cuidadores en la atención hospitalaria a corto plazo, para reducir la ansiedad y mejorar el bienestar subjetivo.

Palabras clave: Cáncer; Cuidadores; Yoga; Ansiedad; Atención Plena. 


\section{INTRODUCTION}

Accompanying children and adolescents with cancer in their trajectory of struggle for life results in great suffering to their families, especially to the people who assume the functions of caregiver..$^{1,2}$ They need to assume the provision of care in an unexpected way and learn new meanings, attitudes and skills to perform this pursuit. ${ }^{3}$ These individuals' life becomes intensely overloaded, with changes in the family routine, relinquishments of personal, social and professional activities, and financial implications. . $^{2,5}$ In addition, the overload caused by this pursuit can have a psychoemotional repercussion on these family members and affect their relationship with their children and/ or adolescents. ${ }^{6}$

Uncertainty and insecurity are present in these individuals' life, and the final goal of the experience is not necessarily the cure of cancer, but the way in which each stage of the process was experienced. ${ }^{7}$ Therefore, the caregivers' psychological adaptation to the children and adolescents' situation can generate a positive impact on the management of the disease, providing them with a more balanced coping perspective. ${ }^{8}$

Caregivers are inserted in a social context and need to be considered in their entirety. ${ }^{2}$ In the last decade, many studies showed the need of supportive interventions that mitigate the overload borne by caregivers, promote their physical, social and emotional wellbeing and, therefore, improve their quality of life..$^{2-8}$

Yoga is a millenary philosophical and practice system, with the purpose of self-perception and self-knowledge, which assists individuals in their physical, psychological, spiritual and social dimensions. This proposal leads practitioners to focus on the present moment, to perceive themselves physically and mentally, and to establish a connection between body and mind. Hatha Yoga, its main branch in the Western world, uses body poses, breathing exercises, relaxation and meditation to fulfil this purpose, and is considered a valuable instrument for health professionals because it views individuals in their totality..$^{9,10}$

The utilization of yoga or of its techniques in an isolated way composes a set of practices self-administered by practitioners, related to complementary and integrative medicine. In science, these practices have been frequently associated with concepts of philosophical traditions that promote body and mind integration. They are offered to individuals in clinical trials as an integral part of intervention programs that aim to reduce the psychophysical symptoms of the stress they experience. Although these trials are still incipient, they have shown benefits to the health of caregivers of individuals in different health conditions. ${ }^{11,12} \mathrm{We}$ have not found a study in the literature that assesses the effects of this practice on the population of caregivers of children and adolescents with cancer.

Based on the information provided above, this study aims to investigate the effects of the Hatha Yoga intervention on levels of anxiety, subjective well-being, mindfulness and awareness of caregivers of children and adolescents undergoing cancer treatment.

\section{METHOD}

This is a randomized controlled trial carried out at Hospital Infantil Nossa Senhora da Glória (HINSG), the reference Children's Hospital of the Great Vitória area, located in the city of Vitória, state of Espírito Santo, Southeastern Brazil, in the period from September 2016 to September 2017.

The participants were caregivers of children and adolescents admitted to HINSG as new cases of cancer for treatment. These individuals were older than 18 years, accompanied the children or adolescents for a minimum period of 40 hours per week, and had never had previous contact with yoga, meditation or similar techniques. The following cases were excluded: hospitalizations or deaths over very short periods, which prevented us from inviting the caregiver to participate in the study; hospitalizations in which the patient's clinical condition was already in an advanced and irreversible state, that is, the patient was on palliative care; and cases in which the volunteer had previous knowledge of the patient's diagnosis. When more than one caregiver took turns to assist the same child or adolescent, only one volunteer was allowed to participate, selected through the criteria explained above. If all the caregivers were suitable for participation, one of them was drawn.

The program Bioestat 4.0 was used to determine sample size for the clinical trial, taking into account the means and standard deviations of the parameters that were going to be assessed. The results of the anxiety scale (described below) were used as the basis for calculation. The control group (8.12 \pm $3.80)$ and the experimental group $(4.88 \pm 3.34)$ were compared in the anxiety variable. The minimum sample size to detect the difference found was 20 patients in each group. ${ }^{13}$

Of the 66 cases of cancer occurred in the data collection period, 48 volunteers were eligible. They were allocated in the clinical and control groups in a random sequence, pre-defined by the program Statistical Package for the Social Sciences (SPSS) and known only by the professional in charge of screening the participants. The volunteers were allocated to a group right after the diagnosis of cancer of the individuals they assisted was confirmed. Overall, 18 individuals were excluded, either because they did not fit the criteria or because they did not accept to participate in the study. During the intervention period, 12 participants ceased to participate in the study. The reasons for this were: impossibility to continue assisting the child/adolescent in the study's period (for health reasons or personal problems); worsening of the child's or adolescent's health status or death during the intervention period; hospital discharge before the completion of the study; or unjustified evasions.

Therefore, the sample was composed of 36 individuals: 18 participants in the clinical group and 18 in the control group.

The caregivers were invited to participate in the study up to the seventh day after the diagnosis of cancer was made. All the participants signed a consent document, accepting to participate in the study. On this occasion, an interview was conducted to gather personal identification information and research 
data. With the objective of monitoring and understanding the participants' daily routine, at the end of the interview, all of them received a field diary and orientations to describe, in a free and spontaneous way, their routine and perceptions during the study's period. The participants of the experimental group received the necessary information to perform the practical activities.

The volunteers of the experimental group participated in 4 to 6 Hatha Yoga practices over a period that varied between 4 to 14 days. The volunteers of the control group, in turn, followed the routine of care provision for the children/adolescents without participating in the intervention, during the corresponding period. The number of practices offered to the participants was based on the study by Bernardi et al.., ${ }^{14}$ which shows a significant reduction in the anxiety levels of mastectomized women after six Hatha Yoga practices over a period of 14 days.

At the end of the period, all the volunteers participated in a second interview, in which they answered the questionnaires again and the field diaries were collected.

\section{Instruments for data collection}

A) Form: designed to collect personal data (city of birth, gender, age, marital status, level of schooling, professional activity, religion), and information related to the child/adolescent they were assisting (age, diagnosis, relationship with the child/adolescent, whether they live in the same home, duration of assistance in the study's period).

B) State-Trait Anxiety Inventory (STAI): Instrument composed of two parts, each containing 20 statements. The anxiety trait scale assesses how individuals generally feel in their lives and is measured through the response options: almost always (4), often (3), sometimes (2), almost never (1). The anxiety state scale assesses individuals' anxiety at a certain moment and is measured through the response options: not at all (1); somewhat (2); moderately so (3), very much so (4). The items' score ranges from 20 to 80 points and indicates the following levels of anxiety: low (20 to 40), moderate (40 to 60 ) and high (60 to 80 ). The two parts contain statements in which the scores for the analysis are inverted from $1,2,3,4$ to $4,3,2,1$. They are: trait scale items $1,6,7,10,13,16$ and 19 and state scale items $1,2,5,8,10,11,15,16,19$ and $20 . .^{15,16}$

C) Subjective Well-being Scale (Brazilian version: EBES): Instrument that consists of 62 items, in two parts, that portray individuals' satisfaction with life and recent affective emotions of pleasure and displeasure. The first part contains 47 items distributed in positive and negative affects that assess how the interviewees have been feeling lately, with scores ranging from (1) not at all to (5) extremely. The second part contains 15 items that assess the interviewees' satisfaction or dissatisfaction with life, with scores ranging from (1) I totally disagree to $(5)$ I totally agree. ${ }^{17}$
D) Mindfulness Attention Awareness Scale (MAAS): Instrument that contains 15 questions, with six scores that range from (1) almost always to (6) almost never, concerning the respondent's state of attention to events of everyday life. ${ }^{18,19}$

E) Ways of Coping Scale (Brazilian version: EMEP): Instrument composed of 45 items containing thoughts and acts used by people to deal with the internal or external demands of a stressful encounter. Four ways of coping are identified: problem-focused, emotionfocused, seeks religious practices/wishful thinking and seeks social support. Answers are given according to 5 scores $\left(1=\right.$ I never do it; $5=\mid$ always do it). ${ }^{20}$

F) Field Diary: The volunteers were instructed to write on a daily basis or to ask someone to write for them about their routine of activities and their impressions during the period of the study.

\section{Intervention}

Practices lasted 35 minutes and were applied individually by a qualified instructor at a quiet place, with mats and pillows being used as support material. Their protocol is composed of the following stages:

- Reception and interiorization of volunteers (1 minute): The participants, in supine position, were asked to: seek to relax, disconnect from worries and external noises, breathe freely and focus on the present moment.

- Performance of psycho-physical poses (20 minutes): The volunteers performed a series of body poses in the standing, sitting and lying positions, holding each pose while perceiving the air coming in and getting out, breathing 5 to 10 times in each fixed pose, according to the need of each individual. During the practice of these poses, specific aspects were emphasized by the repetition of short sentences: "be conscious of the sensations produced by the exercises; focus on the present moment; don't forget to pay attention to your breathing; seek stability, firmness and comfort in the pose you're performing; firmness doesn't mean rigidity; once your pose is stable, relax any unnecessary effort to remain in it longer; comfort can be experienced in any pose, just respect your personal limit".

- Performance of breathing exercises (5 minutes): Sitting cross-legged, the volunteers performed abdomen and chest expansion while prolonging expiratory time.

- Relaxation moment (6 minutes): The volunteers, in supine position, were asked to: close their eyes, seek comfort, disconnect from external sensations, turn their attention to the present moment, to the contact with breathing and with their body segments.

- Preparatory exercises for meditation (3 minutes): In the sitting position, in an alert and comfortable condition, the participants exercised attention to the present moment. The need to persevere and to be patient with themselves was stimulated in the performance of the exercise. 
After each intervention, the participants had time to ask questions and give their testimonies. In addition, they received a DVD and a handbook with instructions for the practice of Hatha Yoga and were encouraged to practice it whenever possible.

When the control group ended their participation in the research, its members were invited to practice Hatha Yoga and received the material with instructions for practice.

\section{Statistical data analysis}

For the statistical data analysis, we used the Statistical Package for the Social Sciences (SPSS) - version 20.0, with level of significance of $5 \%$ and $p \leq 0.05$ (95\% confidence interval). Means and medians were compared through the Mann-Whitney test (comparisons between the control and clinical groups) and through the Wilcoxon test (intragroup comparisons before and after the intervention). The qualitative variables were associated through the chi-square test.

\section{Ethical aspects}

The study was approved by the Research Ethics Committee of Universidade Federal do Espírito Santo (UFES), protocol no. 1.727.171, and by the Brazilian Clinical Trials Registry, protocol RBR-3vz3nd.

\section{RESULTS}

The characterization of the sample, whose qualitative variables are described on Table 1 in absolute values and percentages, signals that there was a difference between groups only in the comparison of the assisted children's and adolescents' diagnosis $(p \leq 0.05)$. While in the control group, non-solid tumors (leukemia and lymphoma) affected the majority of the sample (89\%), in the group that participated in the intervention, the variety of tumor types occurred in a more homogeneous way: $44 \%$ of non-solid tumors versus $56 \%$ of solid tumors (the other types of tumors). In the other variables, there is homogeneity between categories, as p-values are $>0.05$.

The sample was mostly composed by women who practiced Hatha Yoga (94\%) or who constituted the control group (78\%). The great majority of the participants were mothers and fathers and lived in the same household as the assisted children/ adolescents. The age distribution percentage of the assisted individuals was characterized by a higher concentration of children aged up to 4 years in the control group (61\%), while this distribution occurred in a more balanced way in the clinical group: $22 \%$ aged up to 4 years, 33\% aged between 5 and 10 years, $22 \%$ aged between 11 and 14 years, and $22 \%$ older than 15 years.

The participants' age group varied between 18 and 50 years, with the majority being aged 31 to 40 years (44\%). Most of them lived with a partner (78\%) and $50 \%$ declared themselves Protestants.

All the participants had some level of schooling, and $58 \%$ attended school for more than 9 years. The majority of them practiced a professional activity $(72 \%)$ with no employment relationship; therefore, they stopped working to assist the child/ adolescent (44\%). The period of assistance was characterized by dedication during most of the time alternated with short periods in which another caregiver assumed the assistance (53\%), followed by full-time assistance (39\%), and by more than one caregiver taking turns during equivalent periods (8\%).

Table 2 shows the behavior of the variables way of coping, anxiety trait and state, subjective well-being and satisfaction with life in its positive and negative affects, and mindfulness and awareness. While the measures of anxiety state, subjective well-being, and mindfulness and awareness were compared between groups before and after the intervention, anxiety trait and ways of coping were assessed only in the initial interview, with the purpose of learning about the individuals' profiles to be able to analyze them afterwards.

The most used way of coping by the participants was very similar, with means and medians that were quite close in the two groups and p-values higher than 0.05 . 'Seeking religious practices and wishful thinking' was the most frequent finding $(p=0.963)$, followed by 'problem-focused coping' $(p=0.279)$, 'seeking social support' ( $p=0.628)$, and 'emotion-focused coping $(p=0.481)$.

The participants of the clinical and control groups presented a moderate anxiety trait. When the groups were compared, we found that the means were very similar; therefore, there was no difference between them $(p=0.673)$, which shows the heterogeneity of the sample. The same occurred with the initial anxiety state, characterized by moderate anxiety $(p=0.864)$. At the end of the intervention period, the two groups reduced their anxiety levels in a significant way $(p=0.001$ in the clinical group and $p=0.014$ in the control group), with a significant statistical difference between them $(p=0.001)$ : while the control group continued to present moderate anxiety, the individuals who practiced Hatha Yoga presented low anxiety after the intervention.

As for participants' subjective well-being, we found a difference between groups in the initial assessment of positive affects $(p=0.001)$ in the comparison between means and medians (69.5 and 73 in the clinical group and 72.1 and 71 in the control group, respectively). After the intervention period, the HathaYoga practitioners increased their levels of positive affects $(p=0.008)$ while the individuals of the control group presented a non-significant decrease in these levels $(p=0.286)$. On this occasion, there was a difference between the control and the experimental groups $(p=0.005)$. The levels of negative affects decreased in a significant way in the practitioners $(p=0.001)$, and the levels of satisfaction with life did not present relevant alterations in their positive and negative aspects in the two groups ( $p>0.05)$.

Mindfulness and awareness levels, in turn, were similar between groups at the initial moment $(p>0.05)$ and did not present significant alterations at the end of the intervention period $(p>0.05)$. 
Table 1. Characterization of the study's participants.

\begin{tabular}{|c|c|c|c|c|c|c|c|c|}
\hline \multirow{2}{*}{ Variable } & \multirow{2}{*}{ Category } & \multicolumn{2}{|c|}{ Total } & \multicolumn{2}{|c|}{ Clinical } & \multicolumn{2}{|c|}{ Control } & \multirow{2}{*}{ p-value* } \\
\hline & & $\mathbf{N}$ & $\%$ & $\mathbf{N}$ & $\%$ & $\mathbf{N}$ & $\%$ & \\
\hline \multirow{2}{*}{ Gender } & Male & 5 & $14 \%$ & 1 & $6 \%$ & 4 & $22 \%$ & \multirow{2}{*}{0.148} \\
\hline & Female & 31 & $86 \%$ & 17 & $94 \%$ & 14 & $78 \%$ & \\
\hline \multirow{4}{*}{ Participant's age group } & up to 20 years & 1 & $3 \%$ & 1 & $6 \%$ & 0 & $0 \%$ & \multirow{4}{*}{0.459} \\
\hline & 21 to 30 years & 11 & $31 \%$ & 6 & $33 \%$ & 5 & $28 \%$ & \\
\hline & 31 to 40 years & 16 & $44 \%$ & 6 & $33 \%$ & 10 & $56 \%$ & \\
\hline & 41 to 50 years & 8 & $22 \%$ & 5 & $28 \%$ & 3 & $17 \%$ & \\
\hline \multirow{4}{*}{ Marital status } & Single & 4 & $11 \%$ & 3 & $17 \%$ & 1 & $6 \%$ & \multirow{4}{*}{0.480} \\
\hline & Married, stable union & 28 & $78 \%$ & 13 & $72 \%$ & 15 & $83 \%$ & \\
\hline & Divorced, separated & 3 & $8 \%$ & 2 & $11 \%$ & 1 & $6 \%$ & \\
\hline & Widow(er) & 1 & $3 \%$ & 0 & $0 \%$ & 1 & $6 \%$ & \\
\hline \multirow{2}{*}{ Level of schooling } & Up to 8 years & 15 & $42 \%$ & 9 & $50 \%$ & 6 & $33 \%$ & \multirow{2}{*}{0.310} \\
\hline & 9 years and more & 21 & $58 \%$ & 9 & $50 \%$ & 12 & $67 \%$ & \\
\hline \multirow{2}{*}{$\begin{array}{l}\text { Relationship with the } \\
\text { assisted individual }\end{array}$} & Mother, father & 33 & $92 \%$ & 15 & $83 \%$ & 18 & $100 \%$ & \multirow{2}{*}{0.070} \\
\hline & Grandmother, grandfather & 3 & $8 \%$ & 3 & $17 \%$ & 0 & $0 \%$ & \\
\hline \multirow{2}{*}{$\begin{array}{l}\text { Lives with the assisted } \\
\text { individual? }\end{array}$} & Yes & 35 & $97 \%$ & 17 & $94 \%$ & 18 & $100 \%$ & \multirow{2}{*}{0.310} \\
\hline & No & 1 & $3 \%$ & 1 & $6 \%$ & 0 & $0 \%$ & \\
\hline \multirow{4}{*}{$\begin{array}{l}\text { Age group of the } \\
\text { assisted individual }\end{array}$} & Up to 4 years & 15 & $42 \%$ & 4 & $22 \%$ & 11 & $61 \%$ & \multirow{4}{*}{0.108} \\
\hline & 5 to 10 years & 8 & $22 \%$ & 6 & $33 \%$ & 2 & $11 \%$ & \\
\hline & 11 to 14 years & 7 & $19 \%$ & 4 & $22 \%$ & 3 & $17 \%$ & \\
\hline & 15 years and older & 6 & $17 \%$ & 4 & $22 \%$ & 2 & $11 \%$ & \\
\hline \multirow{3}{*}{$\begin{array}{l}\text { Period of dedication to } \\
\text { the assistance }\end{array}$} & Full-time & 14 & $39 \%$ & 7 & $39 \%$ & 7 & $39 \%$ & \multirow{3}{*}{0.824} \\
\hline & Took turns, largest period & 19 & $53 \%$ & 9 & $50 \%$ & 10 & $56 \%$ & \\
\hline & Took turns, equal period & 3 & $8 \%$ & 2 & $11 \%$ & 1 & $6 \%$ & \\
\hline \multirow{3}{*}{ Professional activity } & Yes, on a leave & 10 & $28 \%$ & 6 & $33 \%$ & 4 & $22 \%$ & \multirow{3}{*}{0.407} \\
\hline & No & 10 & $28 \%$ & 6 & $33 \%$ & 4 & $22 \%$ & \\
\hline & $\begin{array}{l}\text { Yes, interrupted to provide } \\
\text { assistance }\end{array}$ & 16 & $44 \%$ & 6 & $33 \%$ & 10 & $56 \%$ & \\
\hline \multirow{4}{*}{ Religion } & None & 3 & $8 \%$ & 1 & $6 \%$ & 2 & $11 \%$ & \multirow{4}{*}{0.339} \\
\hline & Catholic & 14 & $39 \%$ & 5 & $28 \%$ & 9 & $50 \%$ & \\
\hline & Protestant & 18 & $50 \%$ & 11 & $61 \%$ & 7 & $39 \%$ & \\
\hline & Spiritist & 1 & $3 \%$ & 1 & $6 \%$ & 0 & $0 \%$ & \\
\hline \multirow{2}{*}{$\begin{array}{l}\text { Diagnosis of the } \\
\text { assisted individual }\end{array}$} & $\begin{array}{l}\text { Non-solid tumors (leukemia } \\
\text { and lymphoma) }\end{array}$ & 24 & $67 \%$ & 8 & $44 \%$ & 16 & $89 \%$ & \multirow[t]{2}{*}{0.005} \\
\hline & Solid tumors (other tumors) & 12 & $33 \%$ & 10 & $56 \%$ & 2 & $11 \%$ & \\
\hline
\end{tabular}

\footnotetext{
* p-value of the chi-square test for association.
} 
Table 2. Distribution of the perceptions of anxiety, subjective well-being, mindfulness and awareness, and coping in the clinical and control groups.

\begin{tabular}{|c|c|c|c|c|c|c|c|}
\hline \multirow[b]{2}{*}{ Variables } & \multirow[b]{2}{*}{ Median } & \multicolumn{2}{|l|}{ Clinical } & \multicolumn{3}{|c|}{ Control } & \multirow[b]{2}{*}{ p-value* } \\
\hline & & Mean & $\begin{array}{l}\text { Standard } \\
\text { Deviation }\end{array}$ & Median & Mean & $\begin{array}{l}\text { Standard } \\
\text { Deviation }\end{array}$ & \\
\hline Anxiety trait & 44 & 44.8 & 12.3 & 41 & 42.8 & 10.3 & 0.673 \\
\hline Anxiety state M1 & 56 & 54.8 & 10.6 & 53 & 54.3 & 9.4 & 0.864 \\
\hline Anxiety state $\mathrm{M} 2$ & 33 & 33.8 & 5.1 & 48 & 47.7 & 11.1 & 0.001 \\
\hline State $M 1 \times$ state $M 2$ & \multicolumn{2}{|c|}{$\mathrm{p}$-value** } & 0.001 & \multicolumn{2}{|c|}{$\mathrm{p}$-value** } & 0.014 & \\
\hline Positive affects $M 1$ & 73 & 69.5 & 19.3 & 71 & 72.1 & 10.9 & 0.001 \\
\hline Positive affects $M 2$ & 82 & 81.6 & 19.1 & 70 & 68.2 & 10.6 & 0.005 \\
\hline Positive affects $\mathrm{M} 1$ x M2 & \multicolumn{2}{|c|}{$p$-value ${ }^{* *}$} & 0.008 & \multicolumn{2}{|c|}{$\mathrm{p}$-value** } & 0.286 & \\
\hline Negative affects M1 & 58 & 62.1 & 25.4 & 69 & 66.6 & 18.3 & 0.372 \\
\hline Negative affects M2 & 36 & 39.0 & 11.6 & 53 & 59.1 & 20.9 & 0.839 \\
\hline Negative affects $\mathrm{M} 1$ x M2 & \multicolumn{2}{|c|}{$p$-value** } & 0.001 & \multicolumn{2}{|c|}{$p$-value** } & 0.064 & \\
\hline Positive satisfaction with life M1 & 30 & 29.4 & 7.0 & 31 & 28.4 & 6.4 & 0.696 \\
\hline Positive satisfaction with life M2 & 32 & 30.2 & 6.5 & 30 & 27.8 & 5.8 & 0.214 \\
\hline Satisfaction with life M1 x M2 & \multicolumn{2}{|c|}{$p$-value** } & 0.506 & \multicolumn{2}{|c|}{ p-value** } & 0.311 & \\
\hline Negative satisfaction with life M1 & 16 & 16.3 & 7.9 & 16 & 17.8 & 6.8 & 0.443 \\
\hline Negative satisfaction with life M2 & 17 & 17.6 & 5.1 & 19 & 18.7 & 6.0 & 0.650 \\
\hline Satisfaction with life $\mathrm{M} 1$ x M2 & \multicolumn{2}{|c|}{$\mathrm{p}$-value** } & 0.285 & \multicolumn{2}{|c|}{$p$-value** } & 0.686 & \\
\hline Mindfulness and awareness M1 & 68 & 63.0 & 14.5 & 69 & 63.7 & 13.6 & 0.888 \\
\hline Mindfulness and awareness M2 & 59 & 60.9 & 14.3 & 68 & 64.9 & 12.9 & 0.443 \\
\hline Mindfulness and awareness M1xM2 & \multicolumn{2}{|c|}{$\mathrm{p}$-value** } & 0.452 & \multicolumn{2}{|c|}{$p$-value** } & 0.663 & \\
\hline $\begin{array}{l}\text { Coping focused on seeking religious } \\
\text { practices and wishful thinking }\end{array}$ & 4.14 & 4.03 & 0.47 & 4.14 & 4.06 & 0.44 & 0.963 \\
\hline Problem-focused coping & 4.08 & 4.12 & 0.36 & 3.97 & 4.01 & 0.34 & 0.279 \\
\hline $\begin{array}{l}\text { Coping focused on seeking social } \\
\text { support }\end{array}$ & 3.90 & 3.73 & 0.80 & 3.80 & 3.84 & 0.91 & 0.628 \\
\hline Emotion-focused coping & 1.87 & 1.95 & 0.59 & 2.00 & 2.10 & 0.63 & 0.481 \\
\hline
\end{tabular}

\section{DISCUSSION}

This clinical trial showed that the practice of Hatha Yoga influenced the levels of anxiety and subjective well-being of caregivers of children and adolescents undergoing hospital treatment for cancer.

Similarly to what was found by other studies that analyzed this population, most of the caregivers had a maternal bond with the child or adolescent they assisted. ${ }^{4,8}$ The groups were comparable, except for the diagnosis of the children and adolescents. Whatever the type of neoplasia in the child or adolescent, the diagnosis brings anguish to their families, especially to the relatives who assume the functions of caregiver. ${ }^{5}$ Such consternation has been well explored in the literature and explains the moderate anxiety levels presented by the majority of the volunteers at the initial moment. 6,7

There is evidence that yoga techniques can influence the caregivers' levels of anxiety or not; however, their utilization is always associated with some benefit to these individuals. ${ }^{21,22}$ Yoga practice reduced the levels of anxiety and depression and improved the quality of life of 20 caregivers who assisted individuals with neurological disorders when compared to the 23 individuals of the control group..$^{21}$ In another study, however, at the end of three months, despite improvements in quality of life, there were no significant changes in the anxiety and depression levels of 15 yoga practitioner caregivers of individuals with psychotic disorders when compared to 14 non-practitioner caregivers. ${ }^{22}$ 
Clinical experiments that explore the yoga universe present a great variety of techniques whose borders are not well delimited. This hinders the possibility of reaching a consensus regarding its therapeutic efficacy. ${ }^{22}$ Such investigations, when connected with caregivers, aim to help them deal with the anguish they experience, to value the present moment, and to pay attention to aspects of daily life in an intentional, non-judgmental and non-reactive way. In spite of the diversification of protocols and methods, these experiences have shown benefits to these individuals' health. ${ }^{11,22}$

The reduction in anxiety observed in the two groups of the present study is justified, naturally, by the coping strategies employed by the individuals to overcome stressful situations. The volunteers' preponderant attachment to seeking religious practices and wishful thinking represents the manifestation of their impotence to control the clinical response of their children and adolescents undergoing treatment. Therefore, religiosity and spirituality represent a means on which they deposit their hope for the recovery and cure of the children and adolescents they assist. ${ }^{24}$ On the other hand, their lower intention to resort to emotion-focused coping represents something positive, as this type of coping refers to individuals' personal difficulties, associated with guilt in relation to themselves and others. ${ }^{25}$ The distance between this modality and the others is justified by the high level of coping focused on the stressor agent, a fact that entails seeking for healthcare. ${ }^{20}$

While the emotional benefits deriving from these practices show the caregivers' attempt to control their emotions, clinical interventions that assess these individuals' physiological markers have shown the organism's manifestation in the maintenance of its internal balance. ${ }^{26,27}$ Yoga practice associated with compassion meditation reduced the salivary cortisol levels of 25 yoga practitioners who assisted relatives with Alzheimer's disease when compared to 21 non-practitioners, after eight weeks of practice..$^{26}$ The effects of a chanting modality of meditation called Kirtan Kriya were compared to relaxation conducted by instrumental music in familial caregivers of individuals with dementia. The proposed interventions were practiced on a daily basis for 12 minutes during 8 weeks. At the end, there was an increase in telomerase activity, the enzyme responsible for the integrity of immune cells, in the 23 practitioners of Kirtan Kriya when compared to the 16 relaxation practitioners. ${ }^{27}$

Subjective well-being, also understood as happiness, satisfaction, state of mind and affect, refers to what people think and feel about their lives. This construct presents multiple facets and its assessment involves variables from mental health, physiology, memory and emotional expressions.$^{28}$ In the present study, the Hatha Yoga practitioners increased their positive affects and reduced the negative ones, while the non-practitioners did not present relevant alterations. Although the statistics show an initial difference between groups concerning positive affect levels, in practice, this is irrelevant when we consider the variation in the score of the scale items and the comparison with the second moment; therefore, it did not affect the analysis. These findings have also been observed in other clinical investigations. Although such studies are still incipient, they show potential benefits to the mental health of caregivers deriving from interventions that include yoga and meditation techniques. ${ }^{12,29}$

Thus, one single session of laughter yoga, a modality that combines laughter exercises with breathing, abdominal and meditation exercises, showed improvement in the levels of well-being of 38 caregivers of individuals with Parkinson. The measures included: enthusiasm, level of energy, mood, optimism, level of friendship with group members, level of consciousness in relation to breathing, level of muscle relaxation, and capacity to laugh for no reason. ${ }^{12}$ Another non-controlled study showed reduction in stress and mood disorders over 8 weeks in 44 caregivers of children with chronic diseases and special needs, in a mindfulness-based stress reduction program. Similarly to the present study, the sample was composed mostly of mothers of children in ambulatory follow-up care, with possibility of hospitalization during the intervention period. According to the caregivers, the experience empowered them, as it provided tools for self-care and health promotion that can be used anytime, even in the hospitalization period. ${ }^{29}$

Mindfulness and awareness levels, in turn, did not change during the intervention period. We believe that these levels, which measure individuals' habits and conceptions about their lives, did not change because the study's period was insufficient for the incorporation of changes. Practices over an 8-week period, however, presented a more significant influence on these levels by means of different interventions. ${ }^{29-32}$ In this perspective, an initiative assessed two meditation programs based on spiritual wisdom traditions with analogous functions, but performed in different ways. Mindfulness meditation emphasized, to the 15 participants, the importance of cultivating continuous attention to the present moment and to the daily routine, while meditation based on an eight-point program encouraged the 14 participants to develop concentrated attention by memorizing written fragments, repeating fragments aloud during the day and slowing down. At the end, the researchers found better mindfulness levels in the individuals who participated in the two programs when compared to the results achieved by the 15 controls. The conclusion was that the interventions cultivated similar states of mind; therefore, it is possible to consider them as examples of equifinality, which shows there can be many ways leading to the same objective. ${ }^{31}$

Relationships between meditation practices and increase in attention levels are better clarified by studies that investigate more experienced individuals in meditation techniques, with an adequate period of practice and more sophisticated instruments that point to morphophysiological alterations in their nervous system. ${ }^{33,34}$ They show that such practices perform a protective influence on the aging process and harmful effects of stress, favoring practitioners' longevity. ${ }^{32}$

Our study presented limitations regarding the recruitment of participants, which generated the exclusion of many individuals due to varied factors. Some of them were: many caregivers took 
turns to assist the same child or adolescent, which caused uncertainty concerning their regular return; hospitalizations of patients transferred from other hospitals with previously made diagnoses; hospitalizations in which the patient's clinical condition was in an advanced and irreversible state (palliative care); refusal on the part of some individuals to participate in the study due to religious prohibition or without justification. Very short hospitalization periods (due to early discharge or death) limited the occasions to invite caregivers to participate in the study, which sometimes caused the volunteers' evasion during the intervention period. Other volunteers ceased to participate in the study due to the impossibility to continue assisting the child/adolescent (for health reasons or personal problems), to the worsening of the patient's health status or death, because of early discharges, or without an explicit justification. Furthermore, particularities of the patients' hospital routine and personal circumstances of volunteers from the clinical group made the number of Hatha Yoga practice they performed oscillate: eight participants performed eight practices, five performed six practices and four performed four practices.

Other clinical studies involving interventions to reduce stress in familial caregivers of outpatients have also shown difficulties in the volunteers' adherence to the practices, caused by lack of time and hindrances to access the place, ${ }^{22,35}$ as participation in the practices was not a priority in their pursuit. ${ }^{35}$ However, incentive to home practice can make them more viable within the conjuncture of responsibilities involving care, ${ }^{36}$ and their adaptation to the hospital context make them particularly useful as a self-care and health promotion tool. ${ }^{29}$

In addition, the results of the present study were assessed over a short period of time, determined by the viability of the institution's routine. Although science refers to different benefits for caregivers, the continuity of these gains represents another challenge, as the assistance provided for volunteers during the data collection period constitutes only a stage in their pursuit. A controlled study that investigated the effects of meditation on familial caregivers of patients with Alzheimer's disease confirms this statement. It found that, despite a significant reduction in the dimensions that involve the practitioners' psychological suffering and overload, this decrease was discontinued four months after the intervention. ${ }^{37}$ On the other hand, another initiative found that interventions with different proposals, mindfulness-based stress reduction and community education, can influence, in the long term, anxiety levels and associated parameters of familial caregivers of people with dementia. In this experience, six months after the intervention period, the reduction in anxiety was maintained in the same levels in the two groups, while the improvement in the individuals' mental health was progressive in the mindfulness practitioners and less intense in the other caregivers. The conclusion was that, in the long term, these benefits have not been well defined yet, and these individuals deserve to receive science's attention to identify the necessary support for a continuous practice that brings health gains. ${ }^{38}$

\section{CONCLUSION}

Based on the study's results, we can consider the Hatha Yoga intervention as beneficial to caregivers of children and adolescents with cancer in the short term, as the study showed an improvement in their levels of anxiety and well-being. These results point to the need of including the practice in the daily hospital routine of caregivers of children with cancer, and also to the need of further research on the subject.

\section{REFERENCES}

1. Medeiros EGMS, Leite RFB, Ramos DKR, Almeida LAL. Repercussões do câncer infantil no cotidiano do familiar cuidador. Rev Rene [Internet] 2014 mar/apr; [cited 2019 feb 21]; 15(2):233-9. Available from: http:// www.scielo.br/pdf/reben/v66n2/17.pdf

2. Oliveira JS, Cunha DO, Santos CS, Morais RLGL. Repercussões na vida de cuidadores de crianças e adolescentes com doença oncológica. Cogitare Enferm [Internet]. 2018; [citado 2019 fev 21]; 23(2):e51589. Available from: http://docs.bvsalud.org/ biblioref/2018/06/904957/51589-233962-1-pb.pdf

3. Carreño-Moreno S, Chaparro-Díaz L, Blanco-Sánchez P. Cuidador familiar del niño com câncer: um rol em transición. Rev Latinoam Bioet [Internet]. 2017 jul/dec; [cited 2019 feb 21]; 17(2):18-30. Available from: http://www.scielo.org.co/pdf/rlb/v17n2/1657-4702-rlb-17-02-00018.pdf

4. Andrade SFO, Alves RF, Melo MO, Rodrigues MJ. Qualidade de vida e sobrecarga de cuidadores de crianças com câncer. Psicol Ciênc Prof [internet]. 2014; [cited 2019 feb 21]; 34(4):1014-31. Available from: http://www.scielo.br/pdf/pcp/v34n4/1982-3703-pcp-34-4-1014.pdf

5. Medeiros JRA, Carvalho MAP, Medeiros APG, Dantas GD, Matos LM, Pimentel ERS, et al. Transtorno mental comum em cuidadores de crianças. Rev Enferm UFPE. 2018 mar; 12(3):651-7.

6. Amador DD, Gomes IP, Reichert APS, Collet N. Repercussões do câncer infantil e para o cuidador familiar: revisão integrativa. Rev Bras Enferm [Internet]. 2013 mar/apr; [cited 2019 feb 21]; 66(2):267-70. Available from: http://www.scielo.br/pdf/reben/v66n2/17.pdf

7. Alves DFS, Guirardello EB,Kurashima AY. Estresse relacionado ao cuidado: o impacto do câncer infantil na vida dos pais. Rev Latino-Am Enfermagem [Internet]. 2013 jan/fev; [cited 2019 fev 21];21(1):[aprox.7 telas]. Available from: http://www.scielo.br/pdf/rlae/v21n1/pt_v21n1a10. pdf

8. Kim MY. Factors influencing posttraumatic growth in mothers of children with cancer. J Pediatr Oncol Nurs. 2017 jul/aug; 34(4):250-60.

9. Danucalov MAD, Simões RS. Neurofisiologia da Meditação. São Paulo: Phorte; 2009.

10. Barros NF, Siegel P, Moura SM, Cavalari TA, Silva LG, Furlanetti MR, et al. Yoga e promoção da saúde. Ciênc Saúde Colet [Internet]. 2014 [cited 2019 feb 21]; 19(4):1305-14. Available from: http://www.scielo. $\mathrm{br} / \mathrm{pdf} / \mathrm{csc} / \mathrm{v} 19 \mathrm{n} 4 / 1413-8123-\mathrm{csc}-19-04-01305 . \mathrm{pdf}$

11. Dharmawardene M, Givens J, Wachholtz A, Makowski S, Tjia J. A systematic review and meta-analysis of meditative interventions for informal caregivers and health professionals. BMJ Support Palliat Care [Internet]. 2016 jun; [cited 2019 feb 21]; 6(2):160-69. Available from: https://www.ncbi.nlm.nih.gov/pmc/articles/PMC4583788/pdf/ nihms693936.pdf

12. Caro DS, Brown JLC. Laughter yoga, adults living with Parkinson's disease, and caregivers: a pilot study. Explore (NY). 2016 may/ jun;12(3):196-9.

13. Vadiraja HS, Raghavendra RM, Nagarathna R, Nagendra HR, Rekha M, Vanitha N, et al. Effects of o yoga program on cortisol rhythm and mood states in early breast cancer patients undergoing adjuvant radiotherapy: a randomized controlled trial. Integr Cancer Ther [Internet]. 2009 mar; [cited 2019 feb 21]; 8(1):37-46. Available from: https://journals.sagepub. com/doi/pdf/10.1177/1534735409331456 
14. Bernardi MLD, Amorim MHC, Zandonade E, Santaella DF, Barbosa JAN. Efeitos da intervenção hatha-yoga nos níveis de estresse e ansiedade em mulheres mastectomizadas. Ciênc Saúde Colet [Internet]. 2013; [cited 2019 feb 21]; 18(12):3621-32. Available from: http://www.scielo. $\mathrm{br} / \mathrm{pdf} / \mathrm{csc} / \mathrm{v} 18 \mathrm{n} 12 / \mathrm{a} 18 \mathrm{v} 18 \mathrm{n} 12 . \mathrm{pdf}$

15. Spielberger CD, Gorsuch RL, Lushene R, Vagg PR, Jacobs GA. Manual for the state-traitanxiety inventory. Palo Alto: Consulting Psychological Press; 1970.

16. Biaggio $A M B$, Natalício L. Manual para o inventário de ansiedade traço-estado (IDATE). Rio de Janeiro (RJ): Centro Editor de Psicologia Aplicada (CEPA); 1979.

17. Albuquerque AS, Trocoli BT. Desenvolvimento de uma escala de bemestar subjetivo. Psic Teor e Pesq [Internet]. 2004 may/aug; [cited 2019 feb 21];20(2):153-64. Available from: http://www.scielo.br/pdf/ptp/v20n2/ a08v20n2

18. Brown KW, Ryan RM. The benefits of being present: mindfulness and its in psychological well-being. Personal Soc Psychol Rev [Internet]. 2003; [cited 2019 feb 21]; 84(4):822-48. Available from: https:// selfdeterminationtheory.org/SDT/documents/2003_BrownRyan.pdf

19. Barros VV, Kozasa EH, Souza ICW, Ronzani TM. Validity evidence validity of the brazilian version of the mindful attention awareness scale (MAAS). Psicol Reflex Crit [Internet]. 2015; [cited 2019 feb 21] 28(1):87-95. Available from: http://www.scielo.br/pdf/prc/v28n1/01027972-prc-28-01-00087.pdf

20. Seidl EMF, Tróccoli B, Zannon CMLC. Análise fatorial de uma medida de estratégias de enfrentamento. Psic Teor Pesq [Internet]. $2001 \mathrm{sep} /$ dec; [cited 2019 feb 21]; 17(3):225-34. Available from: http://www.scielo. $\mathrm{br} / \mathrm{pdf} / \mathrm{ptp} / \mathrm{v17n} 3 / 8812 . \mathrm{pdf}$

21. Umadevi P, Ramachandra, Varambally S, Philip M, Gangadhar BN. Effect of yoga therapy on anxiety and depressive symptoms and qualityof-life among caregivers of in-patients with neurological disorders at a tertiary care center in India: A randomized controlled trial. Indian $\mathrm{J}$ Psychiatry[Internet]. 2013 jul; [cited 2019 feb 21]; 55(Suppl 3):S385-9. Available from: https://www.ncbi.nlm.nih.gov/pmc/articles/PMC3768217/

22. Varambally S, Vidyendaran S, Sajjanar M, Thirthalli J, Hamza A, Nagendra HR, et al.Yoga-based intervention for caregivers of outpatients with psychosis: a randomized controlled pilot study. Asian J Psychiatr [Internet]. 2013 apr; [cited 2019 feb 21]; 6(2):141-45.

23. Cramer $\mathrm{H}$, Lauche R, Dobos $\mathrm{G}$. Characteristics of randomized controlled trials of yoga: a bibliometric analysis. BMC Complement Altern Med [Internet]. $2014 \mathrm{sep}$; [cited 2019 feb 21]; 14:1-20. Available from: https:// www.ncbi.nlm.nih.gov/pmc/articles/PMC4161862/pdf/12906_2013 Article_1900.pdf

24. Alves DA, Silva LG, Delmondes GA, Lemos ICS, Kerntopf MR, Albuquerque GA. Cuidador de criança com câncer: religiosidade e espiritualidade como mecanismos de enfrentamento. Rev Cuid [Internet]. 2016; [cited 2019 feb 21]; 7(2):1318-24. Available from: http:// www.scielo.org.co/pdf/cuid/v7n2/v7n2a09.pdf

25. Leite FM, Amorim MHC, Castro DS, Primo CC. Estratégias de enfrentamento e relação com condições sociodemográficas de mulheres com câncer de mama. Acta Paul Enferm [Internet]. 2012; [cited 2019 feb 21]; 25(2):211-17. Available from: http://www.scielo.br/ pdf/ape/v25n2/a09v25n2.pdf

26. Danucalov MAD, Kozasa EH, Ribas KT , Galduróz JCF, Garcia MC, Verreschi ITN, et al. A Yoga and compassion meditation program reduces stress in familial caregivers of Alzheimer's disease patients. J Evid Based ComplementaryAltern Med [Internet]. 2013; [cited 2019 feb 21]; 2013:[aprox.8 telas]. Available from: http://downloads.hindawi. com/journals/ecam/2013/513149.pdf
27. Lavretsky H, Siddarth P, Nazarian N, Cyr NS, Khalsa DS, Lin J, et al. A pilot study of yogic meditation for family dementia caregivers with depressive symptoms: effects on mental health, cognition, and telomerase activity. Int J Geriatr Psychiatry [Internet]. 2013 jan; [cited 2019 feb 21];28(1):57-65. Available from: https://www.ncbi.nlm.nih.gov/ pmc/articles/PMC3423469/pdf/nihms373294.pdf

28. Galinha I, Ribeiro JLP. História e evolução do conceito de bem-estar subjetivo. Psicol Saúde Doenças. 2005; 6(2):203-14.

29. Minor HG, Carlson LE, Mackenzie MJ, Zernicke K, Jones L. Evaluation of a Mindfulness-Based Stress Reduction (MBSR) program for caregivers of children with chronic conditions. Soc Work Health Care. 2006 43(1):91-109.

30. Nyklícek I, Kuijpers KF. Effects of mindfulness-based stress reduction intervention on psychological well-being and quality of life: is increased mindfulness indeed the mechanism? Ann Behav Med [Internet]. 2008 [cited 2019 feb 21]; 35(3):331-40. Available from: https://www.ncbi.nlm. nih.gov/pmc/articles/PMC2517090/pdf/12160_2008_Article_9030.pdf

31. Shapiro SL, Oman D, Thoresen CE, Plante TG, Flinders T. Cultivating mindfulness: Effects on well-being. J Clin Psychol [Internet]. 2008 may [cited 2019 feb 21]; 64(7):840-62. Available from: https://onlinelibrary. wiley.com/doi/pdf/10.1002/jclp.20491

32. Danucalov MA, Kosaka E, Afonso RF, Galduroz JCF, Leite JR. Yoga and compassion meditation program improve quality of life and selfcompassion in family caregivers of Alzheimer's disease patients: A randomized controlled trial. Geriatr Gerontol Int [Internet]. 2015; [cited 2019 feb 21]; 17(1):85-91. Available from: https://self-compassion.org/ wp-content/uploads/2016/06/Danucalov_et_al-2015.pdf

33. Chiesa A. Vipassana meditation: systematic review of current evidence. J Altern Complement Med. 2010 jan; 6(1):37-46.

34. Kozasa EH, Sato JR, Lacerda SS, Barreiros MA, Radvany J, Russel $\mathrm{TA}$, et al. Meditation training increases brain efficiency in an attention task. Neuroimage [Internet]. 2012 jan; [cited 2019 feb 21]; 59(1):745-9. Available from: https://reader.elsevier.com/reader/sd/pii/S105381191 1007531?token=671F9F42323927F886C285771DC23BC8ED1004F 176813546952AD3213BAC5FFFF20C886DE4E2FD5AAD6682C46 BC24917

35. Van Puymbroeck M, Payne LL, Pei-Chun H. A phase I feasibility study of yoga on the physical health and coping of informal caregivers. eCAM [Internet]. 2007 sep; [cited 2019 feb 21]; 4(4):519-29. Available from: https://www.ncbi.nlm.nih.gov/pmc/articles/PMC2176147/pdf/nem075. pdf

36. Waelde LC, Thompson L, Gallagher-Thompson D. A pilot study of a yoga and meditation intervention for dementia caregiver stress. J Clin Psychol [Internet]. 2004 jun; [cited 2019 feb 21]; 60(6):677-87. Available from: https://onlinelibrary.wiley.com/doi/pdf/10.1002/jclp.10259

37. Franco C, Sola MM, Justo E. Reducción del malestar psicológico y de la sobrecarga en familiares cuidadores de enfermos de Alzheimer mediante la aplicación de un programa de entrenamiento en mindfulness (conciencia plena). Rev Esp Geriatra Gerontol [Internet]. 2010; [cited 2019 feb 21]; 45(5):252-8. Available from: https://www.elsevier.es/esrevista-revista-espanola-geriatria-gerontologia-124-articulo-reducciondel-malestar-psicologico-sobrecarga-S0211139X10000818

38. Whitebird RR, Kreitzer M, Crain AL, Lewis BA, Hanson LR, Enstad CJ. Mindfulness-based stress reduction for family caregivers: a randomized controlled trial. The Gerontologist. [Internet]. 2013 aug; [cited $2019 \mathrm{feb}$ 21]; 53(4):676-86. Available from: https://www.ncbi.nlm.nih.gov/pmc/ articles/PMC3709844/pdf/gns126.pdf 